they will be treated as fraudulent, since creditors can only recoup the amount of the cash surrender value created by the premium..$^{6}$

There can be little doubt that both the Silansky and New York positions lack the merits of the approach adopted in the Doethlaff and Ross cases. While the New York rule gives inadequate protection to the insured's dependents, the Silansky approach gives too much latitude to the insured inclined to predatory practice. The Ross-Doethlaff line at least has attempted to balance the interests of creditors with the public policy favoring dependents. Of course, the ideal solution would be an exemption statute clearly limiting the amount of premiums which could be paid annually without danger of being labelled fraudulent. Such statutes fortunately are becoming more frequent. ${ }^{37}$ They not only provide certainty but properly place delicate decisions of public policy in the hands of the legislatures.

"... as if the contrary opinion would blow up Lombard-street." Holt, C. J., in Ward v. Evans*

The following comments explore the relation between legal doctrine and commercial practice by examining two specific problems in the field of insurance law. In each case, a well settled rule of law continues to be challenged by forceful dissents. And in each case, a marked divergence between reasonable lay expectations and the law is evident. In Lord Mansfield's time, it was considered sensible and practical for the courts themselves to investigate the understandings of the commercial world. Probably the proximity of the courts to centers of commercial activity in London was influential in this respect. But the distance between the courts and laymen today may be intellectual as well as physical. The need for law revision has been recognized. Equally necessary is the kind of empirical investigation here recommended.

\title{
FIRE INSURANCE AND CHOICE OF PARTIES: THE VAGARIES OF "MORAL HAZARD"
}

May one interested in the property insured against fire, but not a party to the insurance contract, maintain an action directly against the insurer? It has long been the general rule to deny recovery on the ground that a fire insurance con-

* 2 Raym. Rep. 928, 930 (I702).

${ }^{36}$ In re Goodchild, 10 F. Supp. 49 r (E.D.N.Y., x935); contrast Doethlaff v. Penn. Mutual Life Ins. Co., II7 F. 2d 582 (C.A. 6th, I94I) where a court, in a jurisdiction known for a "liberal" construction approach to such premiums, used a different rule than that limiting creditors' rights to the amount of cash surrender value created by fraudulent transfers. The Doethlaff court allows the recovery of the amount fraudulently transferred, as opposed to the stricter increment theory.

${ }^{37}$ An exemption statute clearly indicating how much money may be devoted to the payment of premiums after insolvency spares the courts the task of moderating the conflict between creditors and dependents. For a compilation of these statutes, see Illinois Ins. Code Ann. 46x (IIl. State Bar Ass'n, 1939). 
tract is a "personal contract of indemnity." Fire insurance is predicated on the existence of an insurable interest ${ }^{2}$ and indemnifies its holder only to the extent of the loss of that interest. Moreover, in fire insurance cases the courts persistently emphasize the notion that the insurer exercises his choice of parties with view to their character and moral integrity. ${ }^{3}$

The logical application of these notions is illustrated by two early English cases. In Rayner v. Preston 4 property subject to an executory land contract was destroyed before the deed was executed. The contract made no reference to the vendor's insurance. After the vendor had collected from his insurance company, the purchaser paid the purchase price and sued the vendor for the insurance proceeds. The court held that the vendee had no right to the insurance money since the policy indemnified only the interest of the vendor, i.e., it was a personal contract of indemnity between the vendor and the underwriter to which the purchaser was not a party; and therefore unless there was an assignment, ${ }^{5}$ the right to the proceeds could not run, even in equity, to the purchaser.

I In re Gorman's Estate, 32I Pa. 292, I84 Atl. 86 (1936); Brownell v. Board of Education, 239 N.Y. 369, 146 N.E. 630 (1925); Draper v. Del. State Grange Mutual Fire Ins. Co., 28 Del. I43, 9I Atl. 206 (I914); Traders' Ins. Co. v. Newman, I20 Ind. 554, 22 N.E. 428 (I889).

${ }^{2} \mathrm{An}$ all-inclusive définition of what constitutes an insurable interest is impossible. But a useful rule of thumb might be: such relation or connection with a property interest, that pecuniary benefit or advantage will be derived from its preservation, or a corresponding loss will be suffered by the happening of the event insured against. Sandlin's Adm'x. v. Allen, $262 \mathrm{Ky}$. 355, 357, 9o S.W. 2d 350, 35I (I936). See also Davis v. Phoenix Ins. Co., IIr Cal. 409, 4I4 (1896); Tyler v. Aetna Ins. Co., I2 Wend. (N.Y.) 507 (I834).

3 It is true that all contracts are in a sense personal and that all contracting parties consider each other's "character and moral integrity"; but it appears that only in the area of fire insurance do the courts emphasize the notion so persistently. See, e.g., In re Gorman's Estate, $321 \mathrm{~Pa} .292$, 295, r84 Atl. 86, 87 (r936); Brownell v. Board of Education, 239 N.Y. 369 , I46 N.E. 639 (1925).

For purposes of the present analysis, contracts generally may be classified into three categories: ( $I$ ) the ordinary business contracts, where the parties bargain for a benefit to be reaped by each within the normal risk of the commercial world (unilateral contracts should fall within this category); (2) contracts which require payment of a sum to a party upon the happening of a particular event, including (a) those generally considered wagers (gambling in the usual sense of the word) and (b) those typified by life insurance where a person having an insurable interest in his or another's life pays a premium so that upon death a sum of money becomes payable; (3) contracts of indemnity, like fire insurance.

Fire insurance, unlike a wagering contract, is based on the existence of an insurable interest, as is life insurance. The latter is distinguishable as involving payment to one who may have suffered no loss, while fire insurance involves the deterrent of indemnity, i.e., payment to the insured only in case of loss and to the extent of loss. It has been suggested that, "[p]ractically, it is not a perfect deterrent, since a few insured persons will burn their own property in the hope of exaggerating the extent of their losses or of converting non-salable property into cash." Patterson, Essentials of Insurance Law $\$ 22$, at 89 (I935).

4 I8 Ch. D. I (I88I).

$s$ It has always been held that fire insurance policies are not assignable before loss. (An assignment after loss is governed by the general rules of assignment.) The theory is that such an assignment may increase the "moral hazard" to be borne by the insurer and thus deny his right to select the parties with whom he will contract. The standard fire policies now in use contain provisions that the policy shall be void if it is assigned before loss, without the written 
The dissenting opinion contended that according to principles of "equity" the insurance ran with the land and that the vendor was a constructive trustee of the proceeds for the benefit of the purchaser. In Castellian v. Preston, ${ }^{6}$ a sequel to Rayner v. Preston, the insurer was permitted to recover the proceeds, since the vendor, having been paid the purchase price in full, had suffered no loss.

Although the notion of a fire insurance contract as a personal contract of indemnity has broken down in the life tenant-remainderman and the vendorpurchaser cases, it has been preserved in the mortgage cases. The separate interests of a mortgagor and mortgagee are each insurable and neither has a right to the money payable on the other's policy. ${ }^{7}$ Even where a mortgagor covenants to keep property insured for the benefit, protection, or better security of the mortgagee, and breaks the agreement by taking out insurance in his own name without assigning it or making it payable to the mortgagee, the agreement to insure has been held to create only an equitable lien on the insurance proceeds in favor of the mortgagee. ${ }^{8}$ And, subjecting insurance funds to the equitable lien

consent of the insurer. (This provision may be dispensed with by a rider or similar negating clause.) The courts have been strict in requiring the insurer's consent. Patterson, Essentials of Insurance Law $\S 49$, at $183-85$ (I935). For a limited adherence to a contrary doctrine, see Central Union Bank v. N.Y. Underwriters' Ins. Co., 52 F. $2 d 823$ (C.A. 5th, I93I) and Whiting v. Burkhardt, 178 Mass. 535,60 N.E. I (IgOI) which recognize the validity of an assignment of a mortgagee's rights under the mortgage (loss payable) clause, accompanied by an assignment of the mortgage, even though the insurer's consent to the assignment was not obtained. Patterson, Essentials of Insurance Law $\$ 49$, at I84 (I935).

${ }^{6} x$ I Q.B.D. 380 ( 1883 ).

7 Farmers' Mutual Ins. Co. v. Young, ro4 Ind. App. r39, ro N.E. 2d 421 (I937); Kozlowski v. Pavonia Fire Ins. Co., Ir6 N.J.L. I94, I83 Atl. I54 (1936); Brant v. Dixie Fire Ins. Co., x79 S.C. 55 , 183 S.E. 587 (r935); Baughman v. Niagara Fire Ins. Co., $x 6_{3}$ Minn. 300, 204 N.W. 32 I (I925); Plum Trees Lime Co. v. Keeler, 92 Conn. I, IOI Atl. 509 (rgI7).

This is also true for all the other property relationships: vendor-purchaser, e.g., Milhous v. Globe \& Rutgers Fire Ins. Co., 16r S.C. 96 , 159 S.E. 506 (r93 r); Brady v. Welsh, 200 Iowa 44, 204 N.W. 235 (I925); Mahan v. Home Ins. Co., 205 Mo. App. 592, 226 S.W. 593 (I920); life tenant-remainderman, cases cited note $x \mathrm{r}$ infra; lessor-lessee, e.g., Hale v. Simmons, 200 Ark. 556, I39 S.W. 2d 696 (I940); Smith v. Royale Ins. Co., I Ix F. 2d 667 (C.A. 9th, I940); conditional seller-conditional buyer, e.g., Nelson v. Nelson Neal Lumber Co., I 7 I Wash. 55, I 7 P. 2d 626 (I932); In re Zitron, 203 Fed. 79 (E.D. Wis., I9r3); Grange Mill Co. v. Western Assur. Co., II8 Ill. 396, 9 N.E. 274 (I886). For a cross-section of cases see Insurance-Right to Proceeds, 92 A.L.R. 559 (I934).

${ }^{8}$ E.g., Wheeler v. Factors \& T. Ins. Co., IoI U.S. 439 (I880); Carter v. Rockett, 8 Paige (N.Y.) 437 ( 1840 ); Robbins v. Milwaukee Mechanics Ins. Co., ro2 Wash. 539, I73 Pac. 634 (IgI8). The equity exists even though the contract provides that in case of the mortgagor's failing to procure and assign such insurance, the mortgagee may procure it at the mortgagor's expense. Nichols v. Baxter, 5 R.I. 49I (1858); Robbins v. Milwaukee Mechanics Ins. Co., IO2 Wash. 539, I73 Pac. 634 (I9I8).

These results are also true in the case of a conditional sales contract where the buyer covenants to insure for the benefit of the conditional seller. E.g., Nelson v. Nelson Neal Lumber Co., I 7 I Wash. 55, I7 P. 2d 626 (I932); In re Zitron, 203 Fed. 79 (E.D. Wis., I913); Grange Mill Co. v. Western Assur. Co., II8 Ill. 396, 9 N.E. 274 (I886). For a cross-section of cases see Insurance-Right to Proceeds, 92 A.L.R. 559 (I934).

The equitable lien is said to arise solely from the unperformed contract to protect; the theory being that since equity regards as done that which ought to have been done, if the 
operates somewhat fortuitously, ${ }^{9}$ for the mortgagor may collect the proceeds and abscond before the lien is created; or he may refuse to take the steps necessary to enforce his insurance claim, upon which the mortgagee's lien depends. ${ }^{10}$

A life tenant and remainderman also have separately insurable interests, ${ }^{2 x}$ and unless there exists a fiduciary relationship ${ }^{2 z}$ or an agreement as to who shall procure insurance, neither one may collect on an insurance policy taken out by the other. ${ }^{13}$ However, the life tenant may generally insure up to the full value of the fee, and upon destruction of the property, collect the whole amount of the proceeds. ${ }^{x_{4}}$ Some courts though have held that a life tenant may insure only

mortgagor having so covenanted, fails to make the insurance payable to the mortgagee, or to assign the same, the fund arising therefrom becomes subject to a lien. E.g., First Nat'l Bank v. Commercial Union Assur. Co., 40 Idaho 236, 232 Pac. 899 (I925); Houston Canning Co. v. Virginia Can Co., 21 I Ala. 232, roo So. 104 (I924); In re Sands Ale Brewing Co., 21 Fed. Cas. No. 12,307 (N.D. Ill., 1872); For the collected cases see Insurance-Right to Proceeds, 92 A.L.R. 559, 56I (1934).

The manner in which this equitable principle operates was made clear in Stebbins $\mathrm{v}$. Westchester Fire Ins. Co., II5 Wash. 623, 634, 997 Pac. 913, 916 (I92I) where the court said that even though the policy of insurance may not have been taken out with a view to complying with the contract or with a view to further the security of the creditor, the intent could make no difference since the contract required that the very thing be done that was done. Northwestern F. \& M. Ins. Co. v. New York Life Ins. Co., 238 Ky. 229, 37 S.W. 2d 67 (I93I). First Nat'l Bank v. Cappellini, I49 Pa. Super. $x_{4}, 26$ A. 2d $x_{99}$ (r942) indicates that there is some authority contra. Nelson v. Nelson Neal Lumber Co., I7x Wash. 55, I7 P. $2 d 626$ (1932); Stearns v. Quincy Mutual Fire Ins. Co., I24 Mass. 6I (I878).

9 Nelson v. Nelson Neal Lumber Co., I7x Wash. 55, x7 P. 2 d 626 (1932); Langford v. Fanning, 7 S.W. 2d 726 (Mo. App. r928).

Io Since the recording statutes serve as constructive notice, it is conceivable that in a mortgage case a court might say that where a covenant to insure is a part of the mortgage, the insurer has been put on notice and his insuring will be deemed an insurance of both interests "as the interests may appear." See note 27 infra.

Ix E.g., In re Gorman's Estate, 32I Pa. 292, r84 Atl. 86 (1936); Bell v. Barefield, 2 I9 Ala. 319, I 22 So. 3 I 8 (I929). For the collected cases see Life Tenant-Insurance-Remainderman, I26 A.L.R. 336, 337 (1940).

${ }^{12} \mathrm{~A}$ fiduciary relationship exists when a provision in the instrument creating the estate imposes a duty to insure. See cases cited in 3 I C.J.S., Estates $\$ 46$, at 59 (I942). I Rest., Property \& I23, subsec. 2 (I936).

${ }_{3}$ E.g., Citizens' Ins. Co. v. Railey, 256 Ky. 838,77 S.W. 2d 420 (r934); Blanchard v. Kingston, 222 Mich. 63I, I93 N.W. 24 I (1923); Millard v. Beaumont, I94 Mo. App. 69, I85 S.W. 547 (rgr6); Spalding v. Miller, I03 Ky. 405, 45 S.W. 462 (I898). For the collected cases see Life Tenant-Insurance-Remainderman, I26 A.L.R. 336, 337 (I940).

This does not mean that one cannot insure for the benefit of the other; but if such insurance is to be effected it must have been the intent of the insuring party to do so. Welsh v. London Assur. Corp., I5I Pa. 607, 25 Atl. I42 (1892); In re Gorman's Estate, $32 x$ Pa. 292, I84 Atl. 86 (I936).

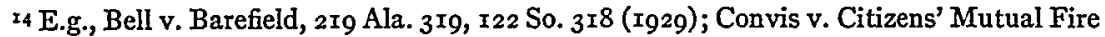
Ins. Co., I27 Mich. 616, 86 N.W. 994 (rgor); Harrison v. Pepper, I66 Mass. 288, 44 N.E. 222 (1896); Western Assur. Co. v. Stoddard, 88 Ala. 606, 7 So. 379 ( 1889 ) (recovery allowed on basis of estoppel because the insurer knew of the partial interest and still insured up to the full value of the property.)

It is clear that this measure of indemnity is different from the usual measure of indemnity. However, it has been strongly argued that the test of market value is neither the only test 
up to the value of the life interest, ${ }^{15}$ while others have said that the insurer may insist on limiting recovery to the value of the life interest even where the premium has been based on the value of the fee. ${ }^{.6}$ These courts, however, refuse to hold that a life tenant's over-insuring is sufficient to give the remainderman a right to a part of the proceeds. ${ }^{17}$ Other courts, feeling that the insurer has received a windfall in that the premium has been calculated on the full value of the property, have held that the life tenant will be deemed to have been acting as a trustee for the remainderman and will be required to use the proceeds for rebuilding or to pay a proportionate part thereof to the remainderman. ${ }^{18}$

nor the proper one in this case. Patterson, Essentials of Insurance Law $\$ 32$, at II2 (I935). The test suggested is "the peculiar value of property to the owner, so long as such value does not exceed the cost of replacement." The feeling underlying this suggestion is that "the life tenant cannot replace the building with a sum of money that represents merely the saleable value of ... [that] interest," and that the life tenant in a sense has a right to the full value since he has the full use of the full value for life. The feeling may be commendable but the rules of law require not that the value of something to someone be found (it may be inestimable), but that the objective present value of the interest be determined. The loss sustained is not the full value of the property inasmuch as the life tenant has never had the full value, which is the present value of the life interest and remainder together. One comment suggests, in speaking of similar breakdowns of the notion of indemnity, that "the public policy behind the doctrine of strict indemnity is not so much based upon indemnity as such; rather, indemnity is regarded as a rule of thumb limiting wagering contracts, and concomitantly, fraudulent fires." Insurance of Mortgaged Property, $88 \mathrm{U}$. of Pa. L. Rev. 347, $35^{6}$ (x939). But such a breakdown of indemnity could itself encourage fraudulent fires since the market value of the life estate is almost always less than the full value of the property!

The existence of a value policy statute would in many instances be nugatory of strict indemnity. Michigan Fire \& Marine Ins. Co. v. Magee, $6 \mathrm{CCH}$ Fire \& Casualty Cases $8 \mathrm{r} 7$ (Mo. App., I949). Patterson, Essentials of Insurance Law $\$ 32$, at II 7 (I935).

rs Doyle v. Ins. Co., r8r Mass. I39, 63 N.E. 394 (rgo2); Beekman v. Fulton County Farmer's Ins. Ass'n, 66 App. Div. 72, 73 N.Y.S. I ro (Igor); Agricultural Ins. Co. v. Yates, Io Ky. L. Rep. 984 (1889). See Blanchard v. Kingston, 222 Mich. 63I, I93 N.W. 24 I (I923).

${ }^{6}$ In re Gorman's Estate, 321 Pa. 292, I84 Atl. 86 ( $\left.x 936\right)$. It was said in Fidelity Ins. Trust \& S.D. Co. v. Dietz, I32 Pa. 36 , 18 Atl. rogo (I89o) that the insurers might have insisted upon limiting recovery to the value of the life estate; but if they did not do so it was of no concern to the remaindermen that the life tenant was to receive the full value of the building. A public policy argument could only be made by the insurer since the remaindermen had no greater claim to the excess than had the life tenant. The fund represented indemnity for loss sustained and did not constitute the proceeds of the property destroyed.

It would seem that the insurers' lack of insistence on strict indemnity defeats the purpose of their insistence that they not be made to bear an increase of moral hazard. This would be particularly true if, as suggested by Professor Patterson, moral hazard "not only embraces the personal qualities or habits of the insured, but also the external factors (see note $\mathrm{I}_{4}$ supra) which tend to cause him to burn his property." Patterson, Transfer of Insured Property in German and in American Law, 29 Col. L. Rev. 69x, 702 (I929).

${ }^{17}$ E.g., In re Gorman's Estate, 32I Pa. 292, I84 Atl. 86 (1936) and cases cited therein. It might be argued that the fact that the insurer had an option to rebuild is sufficient to raise an equity for the remainderman in the cash settlement that followed the insurer's election not to rebuild, since the exercise of the option would have given the remainderman the use of the building upon the death of the life tenant. But this argument overlooks the fact that it is an insurer's option.

${ }_{18}$ Clark v. Leverett, ${ }_{59}$ Ga. 487 , r26 S.E. 258 (1925); Green v. Green, 50 S.C. 514, 27 S.E. 952 (I897). In Clyburn v. Reynolds, 3I S.C. 9 I, 9 S.E. 973 (I889) it was stated that as a matter of public policy there is always a fiduciary duty between the life tenant and remainderman. 
The majority of American courts in the vendor-purchaser cases have rejected Rayner v. Preston, but on a theory which is inconsistent with traditional notions of fire insurance contracts. ${ }^{19}$ They hold that in equity the proceeds of the vendor's policy inure to the benefit of the purchaser. The courts have generally used a constructive trust to accomplish the desired result. The insured is allowed to collect the insurance money notwithstanding the fact that the purchaser is obligated to make full payment; but he is deemed to hold the proceeds as trustee for the purchaser. ${ }^{20}$ The result has been rationalized by the equity rule which describes the purchaser under an executory contract as the equitable owner of the property. A purchaser has even been permitted to institute a suit against the vendor's insurer to compel that insurer to pay the proceeds to the insured

s9 Dubin Paper Co. v. Ins. Co. of North America, 36r Pa. 68, 63 A. 2d 85 (1949); Russell v. Elliott, 45 S.D. 184, I86 N.W. 823 (1922); McGinley v. Forrest, I07 Neb. 309, I86 N.W. 74 (192I); Millville Aerie Fraternal Order of Eagles v. Weatherby, 82 N.J. Eq. 455,88 Atl. 847 (rgI3); Mattingly v. Springfield Ins. Co., 120 Ky. 768, 83 S.W. 577 (I904); Skinner \& Sons Co. v. Houghton, 92 Md. 68, 48 Atl. 85 (rgoo); Williams v. Lilley, 67 Conn. 50, 34 Atl. 765 (I895); Gilbert v. Port, 28 Ohio St. 276 (I876). Contra: Zenor v. Hayes, 228 Ill. 626, 8I N.E. Ir44 (r907); Marion v. Wolcott, 68 N.J. Eq. 20, 59 Atl. 242 (I904); King v. Preston, II La. Ann. 95 (I856); Wilson v. Hill, 3 Metc. (Mass.) 66 (I84I); Aetna Fire Ins. Co. v. Tyler, I6 Wend. (N.Y.) 385 (1836). See Brownell v. Board of Education, 239 N.Y. 369 , I46 N.E. 630 (r925).

In England, Rayner v. Preston was followed in Phoenix Ins. Co. v. Spooner, [1905] 2 K.B. 753; West of England Fire Ins. Co. v. Isaacs, [I897] × Q.B. 226; but was finally rejected by a Parliamentary statute I5 Geo. V, c. 20, $\$ 47$ (I925) which reads as follows: "Any money becoming payable after the date of any contract for the sale of property under any policy of assurance in respect to any damage to or destruction of property included in such contract shall, on completion of such contract, be held a receivable by the vendor on behalf of the purchaser and paid by the vendor to the purchaser on completion of the sale or as soon thereafter as the same shall be received by the vendor." Compare $\S 6_{9}(r)$ of the German Private Insurance Law, quoted in Patterson, The Transfer of Insured Property in German and in American Law, 29 Col. L. Rev. 69I, 693 (I929): "Where property insured has been transferred, all rights and liabilities arising out of the contract of insurance subsequent to the transfer pass from the person effecting the insurance and are vested in, and incumbent on, the transferee." Professor Patterson then says, "The present law effectuates [a temporary] automatic transfer of the insurance contract simultaneously with the transfer of the property. No explicit assignment or agreement is necessary, either as between the transferor and the transferee, or as between either of these and the insurer."

${ }^{20}$ This would not be so in a jurisdiction where the risk of loss is placed upon the vendor. Where this is the case, the vendor is allowed to retain the proceeds. Brownell v. Board of Education, 239 N.Y. 369 , I46 N.E. 630 (I925); Phinizy v. Guernsey, III Ga. 346, 36 S.E. 796 (r90); Vance, Handbook of the Law of Insurance $\$ 172$, at 662 (2d ed., 1930). The rule of law placing the risk of loss upon the purchaser has been violently criticized. Anderson v. Yaworski, I20 Conn. 390, I8I Atl. 205 (I935) (the destruction of the house was a substantial failure of consideration and discharged the purchaser); 4 Williston, Contracts $\$ 940$ (rev. ed., 1937); Langdell, Brief on Equity Jurisdiction 58-65 (2d ed., I926); Griffin, Risk of Loss In Executory Land Contracts, 4 Notre Dame Lawyer 506 (I929); Stone, Equitable Conversion By Contract, I3 Col. I. Rev. $368,385-87$ ( I9I3). The existence of and hardship created by the operation of the rule probably has been one of the strongest inducements to the courts to rule contrary to Rayner v. Preston. What of the notion of splitting the loss? See Loss Splitting in Contract Litigation, I8 Univ. Chi. L. Rev. I53 (I950).

In many instances the purchaser will be credited with a reduction in price equivalent to the amount of the insurance proceeds. Transfer of Insured Property, 24 Tulane L. Rev. 378, 38I (1950). 
who would then, under the trust rationale, hold them for the purchaser. ${ }^{\text {ax }}$ The result is contrary to the logical application of the notions of a fire insurance contract as a personal contract of indemnity. The interest insured is only that of the vendor. ${ }^{22}$ Unlike the life tenant-remainderman case there is nothing here from which it can be said that the vendor was acting for the purchaser in taking out the insurance. ${ }^{23}$

In situations other than the vendor-purchaser case, several other devices have been used or suggested for use in permitting recovery by persons not parties to the insurance contract and not within the contemplation of the insurer at the time the contract was executed. A Texas court allowed recovery by an owner on the theory that the named insured acted as agent for an undisclosed principal. ${ }^{24}$ Of course the facts may not warrant a finding of agency; and even if a court has been able to establish an agency, the undisclosed principal rule

${ }_{21}$ Dubin Paper Co. v. Ins. Co. of North America, 36I Pa. 68, 63 A. 2d 85 (1949). Cf. Swearingen v. Hartford Fire Ins. Co., 56 S.C. 355,34 S.E. 449 (1899) (mortgage case). Compare the procedure employed in the Dubin case with the discussion of the equitable lien in the text at notes 9 and ro supra.

The financial outcome of the Dubin case is interesting to note. The plaintiff purchaser entered into an agreement to buy property for $\$ 25,000$, but before the contract was completed the property was damaged by fire. The plaintiff in the meantime had insured his interest for $\$ 25,000$, and the vendor had added \$ro, 000 to the already outstanding $\$ 26,500$ worth of insurance he held. The property, valued at $\$ 60,000$, was damaged by the fire to the extent of $\$ 49,353$. Subsequently, the vendee paid the balance of the purchase price and received and recorded a deed from the vendor. A conference between the insurers resulted in the amount of the loss being apportioned and two of the insurers sent drafts to the vendor, who returned them stating that he had received the full purchase price of the property. The vendee claimed it was entitled to the proceeds of these policies and sued the insurance companies and the vendor, claiming that the insurance companies be directed to pay the amounts due under the policy to the vendor's executor who in turn be directed to pay over such proceeds to the vendee. On appeal the court upheld the granting of the prayer for $\$ 49,353$, the amount of the fire damage. The plaintiff not only did not lose anything because of the fire, but he received the benefit of his bargain with the vendor.

${ }^{22}$ The difference between the vendor-purchaser and life tenant-remainderman cases is that the insurer in the first case must pay the vendee even though there is no actual loss by the insured; whereas in the life tenant case the insurer is paying more than the actual loss of the insured.

${ }^{23}$ There is in no sense an over-insuring. At the time the vendor's policies were effected he had an interest up to the full value of the property, unlike the life tenant. It is only at the time the owner sells and receives a part payment that his interest is reduced, and continued payment of the old premium might be said to be over-insuring. The essential difference is, however, that in the life tenant-remainderman case the insurer could have known of the insured's limited interest by inquiring as to the extent of that interest before accepting the premium on the whole property; but in the vendor-purchaser case he would be forced to inquire continually as to whether the owner had sold his property. The latter would be an impossible burden on the insurer. The insurer might avoid that difficulty, however, if he includes in the contract a clause requiring that the insured notify the insurer immediately at the time of a change in the insured's interest. If on the other hand the vendor requests a reduction in future premiums on the basis of his decreased interest the result might be otherwise. Cf. note 56 infra. See also note 37 infra.

${ }_{24}$ Franklin Fire Ins. Co. v. Britt, 254 S.W. $2{ }_{5}$ (Tex. Civ. App. x923). 
itself is not applicable in direct contradiction of the policy provisions ${ }^{25}$ or if the contract involves elements of personal trust and confidence as does the fire insurance contract. ${ }^{26} \mathrm{~A}$ Washington court has even gone so far as to reform an insurance contract to allow recovery by a third party, although there was no familiar basis for reformation. ${ }^{27}$ At most, use of the device involved a dubious construction of the facts to effect an "equitable" solution.

Again, the use of the real party in interest statutes to permit a third party to sue an insurance company directly without some other basis would be conversion of a procedural device to a statutory creation of an otherwise nonexisting substantive right. ${ }^{28}$ The real party in interest must be one "who can discharge the duties created"29 and is not necessarily the person who may ultimately be entitled to the proceeds. In the case of insurance the only party who can discharge the duties is the insured. The cases permitting action by a real party in interest are all based on an "as the interests may appear" or similar clause and thus have applied the statutes properly..$^{\circ}$

${ }^{25}$ If it is "shown ... from the terms of the agreement . . . that the contract was exclusively with the agent personally, the principal does not become a party thereto...." 3 C.J.S., Agency $\$ 276$ (r936). Franklin Fire Ins. Co. v. Shadid, 68 S.W. 2 d ro3o (Tex. Com. App., I934) holds this to be the effect of a "sole and unconditional ownership" clause. The policy under consideration in Franklin Fire Ins. Co. v. Britt, ${ }_{254}$ S.W. $2{ }_{5}$ (Tex. Civ. App., Ig23) had such a clause but the court nevertheless allowed recovery. The court in the Shadid case tried to distinguish the Britt holding by saying that there the unconditional ownership clause had been waived. The opinion in the Britt case, however, gives no indication of such a waiver.

${ }^{26} \mathrm{As}$ long as the contract remains executory the undisclosed principal cannot enforce it against the will of the other party. Birmingham Matinee Club v. McCarty, I52 Ala. 57r, 44 So. 642 (I907); King v. Batterson, I3 R.I. II 7 (I880); Boston Ice Co. v. Potter, I23 Mass. 28 ( 1877$) ; 2$ Am. Jur., Agency $\$ 4$ I $2_{\text {(1936). }}$

${ }_{27}$ Robbins v. Milwaukee Mechanics Ins. Co., I02 Wash. 539, I73 Pac. 634 (xgr8). $A$ made a conditional sale of certain pool tables to $B$ with the stipulation that $B$ insure for the benefit of $A . B$ assigned his interest but remained in possession as agent for the buyer and did insure but not in the original vendor's name. The original vendor, $A$, brought suit to enjoin payment to $B$ and to require payment to be made to $A$. It was held that the insurance agent could have ascertained the true ownership of the property and that in such cases equity would, if necessary, reform the policy so as to benefit the proper party. The decision was based on Gaskill v. Northern Assur. Co., 73 Wash. 668, ${ }_{32}$ Pac. 643 (1913), where the agent had actual knowledge of the proper ownership of the property and the insurance company had intended to insure the proper party. The latter case was one of simple mistake. The facts of the Robbins case on the other hand indicate no mistake. The court in effect charged the insurer with knowledge of the conditional sales contract when it actually had none.

${ }^{8} \mathrm{The}$ real party in interest statutes have been interpreted to be procedural only, creating no new substantive rights. 2 Williston, Contracts $\$ 366$ (rev. ed., I936); Clark, Code Pleading c. $3, \S 25$ (2d ed., 1947).

29 Kusmaul v. Stull, $35^{6}$ Pa. 276, 280, 5 I A. 2d 602, 604 (I947); Clark, Code Pleading c. 3, $\S 22\left(x_{928)}\right.$.

${ }^{30}$ Capital Fire Ins. Co. v. Langhorne, 146 F. $2 d 237$ (C.A. 8th, I945) (vendor-vendee, as the interests may appear); Aetna Ins. Co. v. Robinson, $21_{3}$ Ind. 44, 9 N.E. 2 I I38 (I937) (vendor-vendee, loss payable clause); Riley v. Federal Ins. Co., 6o Ga. App. 764, 5 S.E. 2d 246 (1939) (mortgagor-mortgagee, as the interests may appear); Hartford Fire Ins. Co. v. Bleedorn, 235 Mo. App. 286, 132 S.W. 2d 1066 (r939) (same); Marcy v. New Hampshire Fire Ins. Co., 
Finally, courts in which persons other than the named insured would be allowed to recover under a third party beneficiary theory must evade the requirement that both the original parties to the contract intend that the third party be a beneficiary, ${ }^{3 x}$ or draw dubious conclusions of fact to find such an intent. A covenant to insure may evidence the covenantor's intent. In case of breach equity will disregard his real, but subjective intent not to insure, and will regard the actual insuring as evidence of intent to comply with the covenant. ${ }^{32}$ But the insurer's intent is not so easily found. To find such intent implied as a matter of law is but another device designed to effect a particular result.

In the case of fire insurance policies which contain "as the interests may appear" or similar clauses ${ }^{33}$ it is neither illogical nor devious to hold that a purchaser may maintain an action upon the vendor's policy directly against the insurer. ${ }^{34}$ The insurer has explicitly stated his intention to assume the specific risks involved, knowing that this would, in the end, involve liability to persons not known to the insurer at the time of the contract. The insurer has made a promise to insure the property ${ }^{35}$ and pay the proceeds to all who may show an interest within the contemplation of the parties when the contract was executed..$^{36}$

54 Minn. 2, 55 N.W. Ir3o ( 1893 ) (same); Kelner v. Fire Ass'n of Philadelphia, r28 Wis. 233, I06 N.W. 1060 (rgo6) (bailor-bailee, as the interests may appear). For warehouseman cases see cases cited note 36 infra.

${ }^{3 x} 2$ Williston, Contracts $\S 347$ (rev. ed., I936); 4 Corbin, Contracts c. 4I (I95I).

${ }^{32}$ This is under the equitable maxim that equity regards as done that which ought to have been done. See note 8 supra.

33 "On account of whom it may concern" came from and is primarily used in marine insurance policies. "In trust or on commission" is generally used in policies covering warehouse goods.

34 Capital Fire Ins. Co. v. Langhorne, $x_{46}$ F, 2 d 237 (C.A. 8th, I945). "It is not forbidden by law that a policy should be so framed that the insurance shall be inseparably attached to the property meant to be covered, so that successive owners, during the continuance of the risks, shall become, in turn, the parties insured." Waring v. Indemnity Fire Ins. Co., 45 N.Y. 606, 6II (I87x).

35 Patterson speaks of this problem in terms of assignment and says, "The insurance of mechandise ... 'in trust or on commission' makes the insurer's consent to the transfer of the property unnecessary and even dispenses with any formal assignment of the policy." Patterson, Essentials of Insurance Law $\$ 49$, at I 84 (I935).

${ }^{36}$ Generally a warehouseman is answerable to the owner of goods for the proceeds of insurance received after loss when the policy is taken out by the former either voluntarily or pursuant to an express or implied agreement. For the collected cases see WarehousemanProceeds of Insurance, 52 A.L.R. I409 (1928).

In the case of fire policies which cover goods held by the insured as bailee or warehouseman, under an "in trust or on commission" clause, it is generally held that the owner of the property, as the real party in interest or the party for whose benefit the policy was taken out, may maintain an action upon the policy directly against the insurer. For the collected cases see Insurance Policy-Who May Sue, 6r A.L.R. 720, 721 (I929). This general rule may be limited by the terms of the insurance policy. For example, in the case of provision for adjust- 
An arguable basis for a comparable result may be found in the cases where one party procures insurance beyond the value of his own interest. If, for example, a life tenant insures up to the value of the fee and the premium is based on the full value of the property, although the insurer has not expressly stated his intent, he might be deemed to have assumed the risk of liability to an unknown person. It may be hard to understand why an insurance company can continue to collect a premium based on the full value of the property and still not be liable for payment on that basis. But the insurer has no actual knowledge that the insured's interest is partial, and there is no justifiable basis for imputing such knowledge to him unless a general duty to inquire as to the extent of the insured's interest can be imposed upon him. ${ }^{37}$ The most that has ever been imposed upon an insurer is a burden to inquire about the condition of the property or the "moral hazard" he is to assume, since the insured is only under a duty not to conceal material facts fraudulently..$^{8}$

If a duty to inquire were imposed on the insurer ${ }^{39}$ a third party would clearly have rights in cases of over-insuring. An exploratory inquiry ${ }^{40}$ reveals that the discrepancy between the actual inquiries now made as to the client's legal interest and any inquiries that ought to be made is not great. The agents rarely

ment with and payment to the bailee, a direct action could be maintained only if the bailee failed to act properly. Wilson \& Co. v. Hartford Fire Ins. Co., Igo App. Div. 506, 179 N.Y.S. 867 (I920), aff'd 229 N.Y. 612, x29 N.E. 929 (I920).

Where a statute requires a warehouseman to insure for the benefit of his bailors, the bailor may maintain an action, as the real party in interest, against the insurer, even though the warehouseman was the sole named insured in a policy without any "in trust or on commission clause," and even though the warehouseman started the fire and was himself barred from maintaining the action. In Millers Nat'l Ins. Co. v. Bunds, r 58 Kan. 662, r49 P. 2d 350 (r944), the court said that the insurance contract was really two contracts, one with the warehouseman, and one with the bailor. See also Gardner v. Freystown Mutual Fire Ins. Co., 35० Pa. I, $37 \mathrm{~A}$. 2d 535 (1944).

37 It could be argued that since other parties who have insurable interests in insured property probably tend to rely on the insurer's promise and since the insurer knows this, it would not be unreasonable to require an insurance company to inquire as to the nature of the insured's interest. In the case of over-insuring therefore, the insurer would be expected to discover that the insured had only a partial interest. If an insurer over-insures, the knowledge he would have had, had he inquired, could thus be imputed to him, and he would be deemed to have clearly manifested his intent to insure the interest of a third party. The objection to this argument is that reasonable reliance can be found only where there is a covenant to insure, in which case the covenantor would have an insurable interest up to the full value of the property. Patterson, Essentials of Insurance Law $\$ 32$, at II3 (I935). There would then be no over-insuring and the insurer's inquiry or lack of it could not possibly demonstrate his intent to insure the interest of a third party.

${ }^{38}$ Patterson, Essentials of Insurance Law $\S 87$, at 386 (r935).

39 The arguments for imposing a duty to inquire are based on the equitable notions described in the text. See p. 124 infra. See also note 70 infra.

$4^{\circ} \mathrm{A}$ questionnaire was prepared and distributed to a group of Chicago insurance agents picked at random from the telephone classified directory. Forty replies were received. The returned copies of the questionnaire are at present on file in the Law Library of the University of Chicago. 
inquire as to whether the client is a life tenant or a remainderman. The probable explanation is that since the law generally gives the life tenant a right to insure and collect the proceeds up to the full value of the property, there is no need for such inquiry. If the law were otherwise the need for inquiry would be very definite. The fact that many agents do not inquire as to whether a client is a conditional seller or buyer may be explained by the fact that many do not handle such cases. It was found, however, that all agents do inquire as to whether the client was a mortgagor or mortgagee and that the great majority make inquiries as to whether the client was a lessor or lessee, or a vendor or purchaser. Thus the imposition of a duty to inquire and the entailing legal results may not be too onerous.

In Spires v. Hanover Insurance Co., ${ }^{4}$ the preservation of the principles of the fire insurance contract were pitted against the seeming "equity" of a third party's claim. The plaintiff landlord leased certain land and buildings, the lessee convenanting "to keep the buildings now erected or to be erected ... insured against loss by fire" and to keep all the leased premises in proper repair..$^{2}$ The lessee procured a fire insurance policy from the defendant but in his own name. When the buildings were destroyed by fire, the lessee settled with the insurer. His settlement, however, gave him an amount equal to the value of the new buildings only. The lessee refused to file a proof of loss as to the original building or to institute an action against the insurance company. The plaintiff filed a proof of loss and instituted the present action in his own name against the insurance company alone. The court sustained the insurance company's demurrer to the complaint on the ground that it did not show any right of action by the plaintiff against this defendant. The majority stated that the insurance was not taken out for the plaintiff's benefit. "The policy of fire insurance is a personal contract of indemnity against such loss as the insured may sustain; the insurance is not of the property as such, but of the interest of the insured in the properly." 43 Therefore, a lessor may not bring an action on a policy issued in the name of the lessee even though as against the lessee the lessor might ultimately be entitled to the proceeds. The minority suggested agency, third party beneficiary or real party in interest theories as rationales for recovery.

Spires was a hard case because the facts did not warrant a finding of agency so as to invoke the undisclosed principal rule; 44 the plaintiff could not have been

${ }^{4 x} 364$ Pa. 52, 70 A. 2d 828 (I950); noted in 36 Va. L. Rev. 548 (I950) and 35 Minn. L. Rev. IO2 (I950).

${ }^{43}$ These covenants as construed by the court obligated the lessee to restore the original building at the termination of the lease if it had meanwhile been destroyed. See Patterson, Essentials of Insurance Law $\S 32$, at $\mathrm{Ir}_{3}$ (I935).

${ }^{43}$ Spires v. Hanover Fire Ins. Co., 364 Pa. 52, 56, 70 A. $2 d$ 828, 830 (r950).

${ }_{44}$ Since there was no "unconditional ownership" or similar clause in the policy, the application of the undisclosed principal rule would probably have been appropriate. In addition, the insurance contract was probably no longer executory - the premiums having been paid and accepted and the obligation having accrued as of the time of the fire-so as to fall within an exception to the undisclosed principal rule. See notes 25 and 26 supra. 
a real party in interest unless he had a substantive right 45 as a third party beneficiary $; 4^{6}$ and though it is true that the lessee might have been deemed to have insured for the benefit of the lessor, ${ }^{47}$ the facts did not show an intent on the part of the insurer to make the lessor a beneficiary. $4^{8}$ An equitable action against the lessee and the insurance company to settle any cause of action that might exist between the lessor and the lessee and between the lessee and the insurance company, as suggested by the majority, ${ }^{49}$ was probably not a satisfactory remedy. The lessor in the present case might not have been able to serve process on the lessee, or the lessee might have been judgment-proof.50 Moreover, as between the lessee and the insurance company, the latter might have been able to defend on the ground that it had already settled with the insured.5x Probably the only avenue open to the lessor was a direct action against the insurer. However, acceptance of any of the above theories would change the entire basis of fire insurance law from insurance of a particular party's interest to insurance of all the interests (as they may appear) in the property.

On the whole, there is probably little demonstrable justification based on

45 There was no "as the interests may appear" clause. See text at note 30 supra. See also note $3 \mathrm{I}$ supra.

${ }^{46}$ Authorities cited note 28 supra.

${ }^{47}$ The only discernible purpose of the covenant is to give the lessor additional protection by binding the lessee to insure for the lessor's benefit. Under the maxim that equity regards as done that which ought to have been done, the act of insuring has been deemed to have been in compliance with the covenant even though the covenantor insured only in his own name. See note 8 supra. The majority of the court in the instant case, however, stated that it would not so construe the act of insuring.

$4^{8}$ There is not only no clause such as "as the interests may appear" but there is not even an indication that the insurer might have been aware of the existence of the lessor or the lessee's covenant.

Even if over-insuring were held to put an insurer on notice so as to effect insurance of a third party's interest, the present case would not be solved since the lessee, being obligated to replace the building, had an insurable interest in the full value of the property. Patterson, Essentials of Insurance Law $\$ 32$, at II3 (1935).

49 This is the procedure used in Dubin Paper Co. v. Ins. Co. of North America, $361 \mathrm{~Pa} .68$, 63 A. 2 d 85 (1949). See note 21 supra.

so There are no facts available in either the opinion or the record as to these matters. However, since the plaintiff was given three opportunities to amend his complaint (during which time he could have also joined any necessary parties) and did not do so, the fair implication is that the lessee was judgment-proof or service couldn't be had, as suggested.

5x Robinson v. Breuminger, I52 Kan. 644, I07 P. 2d 688 (r940). The mortgage contained a covenant to insure but the mortgagor procured a policy in his own name. Upon destruction of the property the insurance company was notified of the mortgagee's interest. A settlement was made, however, with the mortgagor alone. After the mortgagor converted the money the mortgagee brought an action against both the mortgagor and the insurance company. The court allowed the form of action and held the insurance company liable to the mortgagee, stating that, "whether the insurance company can be held depends upon the facts relative to knowledge or notice to the insurer of the rights of the mortgagee." Ibid., at $65 \mathrm{I}$ and 692 .

As indicated in note 48 supra there is no evidence in either the record or opinion of the Spires case to show that the insurer was aware of the existence of the lessor or the lessee's covenant. 
commercial practice, and there are certainly no sound logical bases for effecting such a change. This becomes clear when one realizes the ease with which the lessor in the Spires case, for example, might have procured insurance himself and made the cost of the premium a part of the rent. If he wished to place the burden of insuring upon the lessee, the lease could have provided that upon the lessee's failure to insure properly, the lessor could then insure and charge premiums to the lessee. Under such a provision, a careless lessor certainly has no equities on his side!

There may, however, be an "equitable basis" for making a change in the present law so as at least to put prospective buyers of fire insurance on notice that third parties will not be protected unless the policy so stipulates. This could be done by requiring insurers who wish to come under the doctrine of Rayner v. Preston to make it clear in the policy that third parties are not included within the coverage. Such a requirement would provide warning to the laymen who may now wrongly conceive of fire insurance as running with the land. $5^{2}$

Probably the general dissatisfaction with the rule of Rayner v. Preston indicates that a fire insurance contract really does have a different meaning for persons who ordinarily buy insurance than it has for professional insurers. The decisions contrary to Rayner 0 . Preston may in themselves give effect to a not unreasonable lay understanding and encourage the public to entertain such an understanding..$^{33}$ It may be felt that the insurance company has assumed a risk for which a full premium has been paid and that it should not be relieved from paying on that basis. ${ }^{54}$ Someone suffers loss from the destruction of the property insured; it may not seem a hardship or injustice to the company to require it to pay the policy. ${ }^{55}$ Even the business public may assume that an executory contract for the sale of insured realty carries the protection of existing insurance

$5^{2}$ The lay conception is postulated in Vance, Handbook of the Law of Insurance $\S \mathrm{r} 72$, at 662 (2d ed., I930); 98 U. of Pa. L. Rev. 766, 767 (I950) noting Dubin Paper Co. v. Ins. Co. of North America, $36 \mathrm{I} \mathrm{Pa.,} \mathrm{68,} 62$ A. 2d 85 (I949); dissent in Rayner v. Preston, I8 Ch. Div. I, I5 (I88I) "I believe it [the fire policy] to be considered by the universal consensus of mankind, to be a policy for the benefit of all persons interested in the property."

53 It was said in John Hancock Mutual Life Ins. Co. v. Fireman's Fund Ins. Co., Io Wash. $2 \mathrm{~d} 3 \circ 3,3 \mathrm{I} 4$, II 6 P. 2d 539, 544 (I94X) that "the insurance would stand as security for the mortgage debt in lieu of the property destroyed"; and in Doty v. Rensselaer County Mutual Fire Ins. Co., I88 App. Div. 29, 32, I76 N.Y. Supp. 55, 57 (I9I9) the court said, "The insurance money takes the place of the house. Whatever interest in the house the plaintiff had, a corresponding interest attached to the insurance which is a substitute for the house." Likewise it has been said that "[t]he property being destroyed, the insurance money stands in lieu thereof." Robbins v. Milwaukee Mechanics Ins. Co., Io2 Wash. 539, 544, I73 Pac. 634, 635 (IgI8). And in Phoenix Ins. Co. v. Mitchell, 67 Ill. 43, 46 (I873): "the insurance money represented the property destroyed...." (I923).

54 See Vanneman, Risk of Loss, Between Vendor \& Purchaser, 8 Minn. L. Rev. r27, r38

ss Ibid. Compare the notion of insurance in the area of workmen's compensation where the underlying principle is that the insurer is in a better position to distribute the cost of the risk throughout the community, working no hardship on any one party. 
policies to the purchaser. ${ }^{6}$ Common sense often seems to substitute the insurance money for the insured property, despite the general rule that the two are not legally connected.

These conceptions as to the nature of fire insurance, however, are not in themselves sufficient basis for making an extensive change from insurance of a particular party's interest to insurance of all the interests in the property. It is necessary to find that there is no justification for the personal contract notion. Rayner v. Preston rests partly on the view that to deny an insurer complete freedom in chosing the insured is to burden him with an unascertainable "moral hazard."

The results of an exploratory inquiry, ${ }^{57}$ undertaken to discover the extent to which insurance agents investigate prospective clients indicate that this emphasis on the personal contract notion may no longer be warranted..$^{8}$ The survey shows that none of the replying agents thoroughly investigate a client unless a special matter indicating that the client may be a bad risk is brought to the attention of the agent.59 The specific inquiries made by each insurance firm vary greatly, depending on such circumstances as the agent's evaluation of the client's appearance or the location of the property to be insured. Twenty-three per cent ${ }^{60}$ of the replying agents make inquiries about the client's fire record. Ten per cent ${ }^{6 r}$ indicate that they inquire into the client's habits in maintaining

${ }^{5}$ Speaking of the automatic transfer of insurance coverage on property which is to be conveyed in the German law, Professor Patterson says that the "automatic transfer . . probably conforms to the transferee's habits and expectations." Patterson, op. cit. supra note I9, at 693. The German law provision is set out in note I9 supra.

There is arguably a significant difference between the case of a vendor selling land and buildings already insured and the case of a vendor (or purchaser) insuring during the life of a land contract. The former is much like an assignment of the existing fire policies. Since such policies are not assignable without the insurer's assent, the automatic transfer and coverage of both interests by the policy may be more reprehensible than such coverage in the second case. There, it would have been possible for the insurer to inquire and discern the two existing interests. Cf. note 23 supra. Consult Insurance Co. v. Updegraff, $21 \mathrm{~Pa} .5^{1} 3$ (I853), where a vendor insured the realty sold, but only partially paid for, in his own name, and paid the premium himself. The court thought it clear that all the parties intended the insurance to cover the vendee's interest as well as the insuring vendor's since the premium charge was adequate for such coverage. In neither case, however, would the insurer have had actual knowledge of the other interest. See note 37 supra.

57 See note 40 supra.

${ }^{8} \mathrm{An}$ insurance survey consisting of a careful listing of insurance needs, noting existing insurance, and recommending needed adjustments or additional insurance, is probably what should be undertaken by each agent in order to assure the client the best possible coverage. For a detailed discussion of the steps in such a survey see Hedges, Improving Property and Casualty Insurance Coverage, I5 Law \& Contemp. Prob. 353, 37I (I950).

59 In some instances no inquiry is made at all unless such circumstances are present.

${ }^{60}$ Forty per cent would be the figure if the computation had been made on the basis of the number of replies indicating that inquiries as to "moral hazard" are made.

ox Eighteen per cent would be the figure if based on the alternative method indicated in note 60 supra. 
and caring for the property, and twenty per cent ${ }^{62}$ inquire as to whether the client has, in the past, received any cancellations of fire policies or rejections of his application for such policies. ${ }^{63}$ On the other hand, forty-five per cent ${ }^{6}{ }^{4}$ make no inquiries at all about the "moral hazard" to be borne by the insurer. ${ }^{65}$ Although these results are in no way conclusive, ${ }^{66}$ they seem to indicate that a great deal of the insurer's protection has been destroyed by the lack of extensive inquiry by the insurance agent. ${ }^{67}$ It may not, therefore, be unreasonable to effect a basic change in the law of fire insurance; $;^{68}$ but it would be sounder to postpone such action until further justification is found in more extensive studies of business practice in this field.

The present alternative is to use some means to guard against common lay misconceptions as to the nature of fire insurance. When it comes to understanding the myriad of technical and often ambiguous clauses of a fire insurance contract, the lay public is in an unequal "bargaining" position compared to the insurer, the expert. The layman is caught in something in the nature of a "fine print trap." 9 The insurer is in a better position to draft an instrument to serve

${ }^{62}$ Thirty-six per cent would be the figure if based on the alternative method indicated in note 60 supra.

${ }^{6}$ Another object of inquiry is the total amount of insurance carried.

${ }^{64}$ This percentage too has been calculated on the basis of the total number of replies.

${ }^{65}$ Premiums seem to be based on the amount of coverage and the condition of the property. The survey indicated that the coverage of more than one interest in the property by a clause such as "as the interests may appear" can be had without any increased premium.

${ }^{66}$ The results are inconclusive for at least two reasons: $(x)$ the interpretation and presentation of the results is necessarily subjective; (2) the sample is much too small. The larger undertaking necessary in order to produce conclusive results would require time and resources not available to the average student or faculty member. An organization of the magnitude of the American Law Institute would be necessary.

A larger undertaking might attempt a classification of kinds of insurance agents, e.g., (I) the single agent with no office, (2) the large firm, (a) in a metropolitan area, (b) in a more rural area, (3) the specialist, (a) handling realty insurance only, (i) business buildings, (ii) homes, etc. The possible classifications are almost limitless but such breakdowns may have significantresults.

${ }^{67} \mathrm{It}$ must be recognized that the insurer's own checking in the home office has not been mentioned. This may be an important element and is certainly worth a separate survey. For some indication, however, that there is little such checking done, and that most of that presently done is valueless, see Patterson, Transfer of Insured Property in German and in American Law, 29 Col. L. Rev. 69r, 706-7 (r929).

${ }^{68}$ The personal contract notion depends, in part, on the assumption that a significant number of fires are fraudulent fires. It has been suggested that "the common carelessness of the American people is the risk assumed by the insurers doing business in the United States." Patterson, op. cit. supra note 19 , at 705, 706. How is this risk increased by a change in ownership? If a fire be proved fraudulent, there is no problem. As for those which cannot be proved Professor Patterson says "the number of persons who have fraudulent fires must be only a fractional percentage of the total number of persons insured against fire, and the crucial question is whether the interests and convenience of honest insured persons should be sacrificed in order to defeat recovery by a small proportion of dishonest persons who succeed in concealing their crimes." Ibid., at 705 .

${ }^{69}$ The lay position today in understanding the words of the fire insurance contract may be comparable to the warranty dilemma which flowered little over a century and a half ago. Warranties were then construed so that even an immaterial breach voided the policy. The 
the needs and understanding of the client and to protect himself by appropriate clauses drawn in clear, readable language. $7^{\circ}$ The insurer may of course further protect himself by properly calculating the premium for the risk he assumes. Placing this burden upon the insurer would probably not be a hardship; there would seem to be enough law protecting third parties to put him on notice..$^{7 x}$

Such a change would be analogous to a development which has taken place in the surety bond cases. The words of the contract of the compensated surety are now interpreted liberally in the interest of the third party laborer and materialman rather than strictly in favor of the surety..$^{72}$ To a lesser degree, a similar development has taken place in the liability insurance cases where courts have held ${ }^{73}$ that the contract should be liberally construed for the protection of third parties unless the language of the contract is clearly to the contrary. Many statutes go even further and require that all liability insurance be carried for the benefit of third parties. ${ }^{74}$ Courts generally deny rights to third parties unless the promisor and promisee of a fire insurance contract intended to create such rights and unless the language of the contract specifically and clearly established them. Instead, the courts could take the position that the insurance contract should be construed liberally for the benefit of third parties unless the words of the policy are clearly and unambiguously to the contrary ${ }^{75}$ and are set out in such fashion that they are not physically obscured.

inequity was perceived by the courts and, through judicial decision, substantial compliance with the warranties became sufficient so long as the deviation was such that it did not or probably would not have affected the issuance of the policy. See Patterson, Essentials of Insurance Law \& 61 (I935).

${ }^{70}$ A distinction should be recognized between the duty to draft aninstrument clearly and the duty to inquire, for instance, as to the extent of the client's interest in theproperty or his need of an "as the interests may appear" clause. The duty to inquire, however, would be imposed for the same equitable reasons that the duty to draft clearly is imposed. See p. I24 supra. See note 39 supra.

It seems that anyone may have an "as the interests may appear" clause upon request and without any additional charge, yet many agents do not offer the suggestion that such a clause be included in the policy. This seems a pity for surely such a suggestion in the appropriate case would be an even more "constructive" aspect of the imposition of a duty to draft clearly.

${ }^{7 x}$ Particularly in the vendor-purchaser cases.

${ }^{72} 4$ Corbin, Contracts $\$ 800$, at $x_{76}$ (I95I). For a thorough analysis of the problem see Campbell, The Protection of Laborers and Materialmen Under Construction Bonds, 3 Univ. Chi. L. Rev. r, 20r (r935).

${ }_{73}$ Ohio Casualty Ins. Co. v. Beckwith, 74 F. 2d 75 (I935); Nèw Amsterdam Casualty Co. v. Jones, $\mathrm{r}_{35}$ F. 2d r9I, I96 (r943); 4 Corbin, Contracts $\$ 807$ (r95 r); Vance, Handbook of the Law of Insurance $\$ 178$, at 684 (2d ed., I930).

74 In New Amsterdam Casualty Co. v. Jones, 135 F. 2d r9r, I96 (1943), the court's public policy decision was in some measure based on such a statute. 4 Corbin, Contracts $\$ 807$ (I95I); Vance, Handbook of the Law of Insurance $\& 178$, at 686 (2d ed., 1930).

75 Professor Schultz in The Special Nature of The Insurance Contract: A Few Suggestions for Further Study, ${ }_{5}$ Law \& Contemp. Prob. 376,378 (1950) says that to some extent such is the law, in spite of lip service to other principles, and that, to the extent such is not the law, it should be. 
This change would effect an insurance of all the interests in the property in the case of ambiguity; though practically it would mean only that liability to third parties must be denied in clear language. Insurance companies would be in the same relative position they are in now. Presently justifiable lay expectations would be checked and the broader change to insurance of all the interests in the property would be properly postponed until it can be fully justified on the basis of more extensive studies into the practical context in which these rules of fire insurance law operate.

\section{THE NONCUMULATIVE CLAUSE AND RENEWED FIDELITY BONDS-PIG IN A POKE?}

In Columbia Hospital for Women v. U.S. Fidelity \& Guaranty Co., ${ }^{\mathrm{x}}$ defendant surety company issued a fidelity bond indemnifying the plaintiff against defalcations by certain named employees, with a maximum indemnity of $\$ 5, \infty 00$ in the case of plaintiff's bookkeeper. Renewal was effected by subsequent issuance of a Blanket Position Bond ${ }^{2}$ affording slightly broader coverage. The second bond had no definite date of termination, but was renewable on payment of annual premiums, subject to the proviso that the payment of such premiums "shall not render the amount of this bond cumulative from year to year." Four years after the original bond was issued, a rider was attached, "extending the term for three years from the renewal date" and respectively substituting the terms "periods," "premium period" and "agreed premiums" for the words "years," "premium year" and "annual premiums" wherever they occurred in the Blanket Position Bond. Three years later, plaintiff discovered that its bookkeeper had embezzled in excess of $\$ 40,000$ over a four year period, $\$ 5,498.32$ during the year before the rider went into effect, and $\$ 3,975.47, \$ I_{3}, 28 \mathrm{r} .45$ and $\$ 17,555.90$ respectively during the three years covered by the bond and rider. The insured accordingly filed a claim for $\$ 18,975.47$ on the theory that the fidelity company's liability was $\$ 5,000$ for each year of coverage. The Court of Appeals for the District of Columbia affirmed the grant of defendant's motion for summary judgment, limiting recovery to $\$ 5,000$.

No authoritative survey has ever been conducted to determine what was an important question in the principal case, what employers really think they

I I88 F. 2d 654 (App. D.C., I95ז).

2 Fidelity bonds can be made out to cover either specifically named employees, or the occupants of designated positions for the time being. The companies have fashioned many different kinds of bonds, containing various combinations of these two basic features. Among the most widely used are the Name Schedule or Fidelity Schedule bonds, covering named employees, with or without indications of position; Position Schedules, bonding the positions listed regardless of which employees occupy them or how often the personnel shifts; and Blanket Position Bonds, covering all employees of the insured employer for the same amount, regardless of position or name. Riegel and Miller, Insurance Principles and Practices 694, 698-703 (3d. ed., r947). 